\title{
Investigation of Salinity Effect on Compressive Strength of Reinforced Concrete
}

\author{
Akinsola Olufemi Emmanuel $^{1}$, Fatokun Ajibola Oladipo ${ }^{1} \&$ Ogunsanmi Olabode E. $^{2}$ \\ ${ }^{1}$ Department of Building Technology, School of Environmental Studies, Yaba College of Technology, Yaba- \\ Lagos, Nigeria \\ ${ }^{2}$ Department of Building, Faculty of Environmental Sciences, University of Lagos, Nigeria \\ Correspondence: Fatokun Ajibola Oladipo, Department of Building Technology, School of Environmental \\ Studies, Yaba College of Technology, P. M. B. 2011, Yaba- Lagos, Nigeria. Tel: 234-805-231-4874. E-mail: \\ ajibolaoladipo@yahoo.com
}

Received: February 15, 2012 Accepted: May 4, 2012 Online Published: May 24, 2012

doi:10.5539/jsd.v5n6p74 URL: http://dx.doi.org/10.5539/jsd.v5n6p74

\begin{abstract}
This study adopt laboratory controlled experiment approach, in order to induce the worst scenario of concrete mix and determine the consequent effect on reinforced concrete element; a mix ratio of 1:3:6 was adopted for the experiment. Reinforced concrete elements were cast using both lagoon and ocean water while fresh water was used as a control experiment. These samples were buried at a depth of $1.5 \mathrm{~m}$ below the ocean and lagoon bed soil characteristics and observed for a period of 150 days. Both the ocean and the lagoon samples increases in compressive strength from $10.65 \mathrm{~N} / \mathrm{mm}^{2}$ and $10.57 \mathrm{~N} / \mathrm{mm}^{2}$ on $7^{\text {th }}$ day to $17.05 \mathrm{~N} / \mathrm{mm}^{2}$ and $18.04 \mathrm{~N} / \mathrm{mm}^{2}$ on the $21^{\text {st }}$ day respectively as against the $14.20 \mathrm{~N} / \mathrm{mm}^{2}$ on $7^{\text {th }}$ day to $17.05 \mathrm{~N} / \mathrm{mm}^{2}$ and $18.04 \mathrm{~N} / \mathrm{mm}^{2}$ fresh water sample. On $14^{\text {th }}$ day fresh water sample has $17.48 \mathrm{~N} / \mathrm{mm}^{2}$ as against $12.10 \mathrm{~N} / \mathrm{mm}^{2}$ and $12.55 \mathrm{~N} / \mathrm{mm}^{2}$ recorded for both ocean and lagoon water samples. The findings revealed that concrete sample cast and cured with fresh water gained appreciable compressive strength over 150 days period while sample cast and cured with ocean and lagoon water slowly increase in strength but lower when compared with fresh water reinforced concrete element. Therefore the study recommended that a rich mix other than 1:3:6 and 1:3:5 be strictly enforced on construction sites for concrete under saline attack, increase concrete cover be used for protection against corrosion, and that non destructive test be carried out on all formworks under vertical loads like slabs and beams before they are stripped.
\end{abstract}

Keywords: salinity, saline environment, compressive strength, reinforced concrete, mix ratio

\section{Background of the Study}

In the vast majority of development that has crept into the building industry, concrete and steel have found their ways so useful and very paramount in the building component. Oyenuga (2004) stated that reinforced concrete is a combination of two dissimilar but complementary materials, namely concrete and steel. Concrete has considerable crushing strength, is durable, has good resistance to fire but offers little or no strength in tension but fair in shear. On the other hand, steel has a very good tensile property, poor resistance to fire (due to rapid loss of strength under high temperature) and very good both in shear and in compression. Thus, a combination of these materials results in good tensile and compressive strength, durability and good resistance to fire and shear. Concrete on its own is a composite material of cement, sand, coarse aggregate (gravel or crushed stone) and water. Its good workability allows it to be easily used in any shape ranging from bulky dam wall, foundation to very thing shell roof. According to Osei (2000) and Water encyclopaedia (2012), great bodies of water covers about five seventh of the earths' surface about $71 \%$ reaching in some places to depth more than ten kilometres $(10 \mathrm{~km})$. Sea water has a total salinity of about 3-5 percent, with quantity of chlorides in the water (e.g. sea water) which tend to cause persistent dampness, efflorescence and corrosion to reinforcement. Deterioration of concrete is rarely due to one isolated cause, (i.e. no one cause could be described as a factor causing degradation of concrete). It then readily follows that, concrete can often be satisfactory despite some undesirable feature (Physical features) but the addition or further adverse factor, damage will be completely done. Therefore, the quality of concrete in a broad sense is considered as a cause or factor that could be responsible for the deterioration of concrete and not any isolated factor. But, in tackling deterioration of concrete, the salinity effect 
must never be left out as it usually come into the scene most especially when water of its constituent is used or when concrete is being worked upon in region of its (salt) reach. This study will be of high importance to the construction team involved in the erection of building especially Builder, Civil and Structural engineer in order to increase their knowledge on how salinity can affect the structural stability and environment of a particular building. The study critically examines to determine the reinforced concrete strength in relation to its mix proportion and its age. It also examines the usual stripping days for formworks and identifies adequate precautions to be taken in the execution of such works. The study assessed coastal region salinity, its measurement and classification and also considers the effect of salt water of coastal areas on the compressive strength of concrete.

\section{Literature Review}

The crust and interior of the earth constitutes the main source of seas. Salinity, which is measured in terms of, dissolved materials per kilogram of sea water or equivalently parts per thousand, represents the total quantity of dissolved salt in seawater. Vicat (1812) opine that the world seawater in most cases has salinity of the range (34-35)\% though the properties of water to dissolved salts tend to vary within the ocean, the major component ions are evenly distributed in ocean water in relatively constant proportion that accounts for the defects and failures of buildings located in coastal areas.

\subsection{Chemical Action of Sea Water on Concrete}

According to Vicat (1812), Prascal et al. (2006) the chemical action of seawater on concrete is mainly due to attack by magnesium sulphate $\left(\mathrm{MgSO}_{4}\right)$. This is worsened by the chloride present in the seawater which retards the swelling that usually characterize the attack by sulphates in seawater which becomes whitish in appearance, more severe attack subjects the set concrete to expansion which leads to spalling and cracking. Finally, the concrete becomes liable and is reduced to soft mud. At first, the strength of the concrete tends to increase during the early stage of attack, but later followed by loss of strength that preceded the resulted expansion. It is equally claimed that potassium and magnesium sulphates (KS, MgS) present in salt water can cause sulphate attack in concrete since they readily react with calcium hydroxide $\left(\mathrm{Ca}(\mathrm{OH})_{2}\right)$ present in the set cement through the hydration of $\mathrm{C}_{3} \mathrm{~S}$ and $\mathrm{C}_{2} \mathrm{~S}$ as depicted below (Bryant, M., 1964).

$$
\begin{aligned}
& \mathrm{S}+\mathrm{CH}+2 \mathrm{H} \mathrm{CSh}_{2}+\mathrm{KH} \\
& \mathrm{S}+\mathrm{CH}+2 \mathrm{H}-\mathrm{CSH}_{2}+\mathrm{MH}
\end{aligned}
$$

Where $\mathrm{K}-\mathrm{KO}$ and $\mathrm{M}-\mathrm{MgO}$

The attack by magnesium sulphate $(\mathrm{MgS})$ is quite demanding as it forms sparing soluble magnesium hydroxide that forces the reaction to the right forming gypsum, $\mathrm{MgS}$ will equally react with the Calcium Sulphate (CSH) gel together with that produced by the reaction of magnesium sulphate while calcium hydroxide combine with silica hydrate $\left(\mathrm{S}^{\wedge} \mathrm{M}\right)$ produced by the reaction with cementation gels to form non cementations product $\left(\mathrm{M}_{4} \mathrm{SH}_{8}\right)$.

Table 1. Major ion composition of sea water

\begin{tabular}{ccc}
\hline Common name & Ions & $(\mathrm{g})$ \\
\hline Sodium & $\mathrm{Na}$ & 10360 \\
Magnesium & $\mathrm{Mg}^{++}$ & 1.294 \\
Calcium & $\mathrm{Ca}^{++}$ & 0.413 \\
Potassium & $\mathrm{K}^{+}$ & 0.387 \\
Strontium & $\mathrm{Sr}^{++}$ & 0.008 \\
Chloride & $\mathrm{Cl}^{-}$ & 19.353 \\
Sulphate & $\mathrm{SO}_{4}^{2-}$ & 2.712 \\
Bromide & $\mathrm{Br}^{-}$ & 0.008 \\
Boron & $\mathrm{N}_{3} \mathrm{~B}_{3}$ & 0.001 \\
Bicarbonate & $\mathrm{HCO}^{3-}$ & 0.142 \\
Fluoride & $\mathrm{F}^{-}$ & 0.001 \\
\hline
\end{tabular}

Source: Laboratory analysis (2009). 


\subsection{Salinity Measurement}

Adebakin (2003) described fresh water as that purified expanse of water, which is devoid of any form of impurities. Whereas, seawater is considered as water containing high percentage of Sodium chloride. Only 2.5 Percent of the world's water bodies is said to be fresh water, the remaining constitute seawater.

The electrical conductivity (EC) of the soil in decisiemens per meter $(\mathrm{ds} / \mathrm{m})$ is a measure of determining the salinity level at site. It is worthy to note that a salinity level of $\mathrm{I} \mathrm{ds} / \mathrm{m}$ is approximately equal to a total soluble salt level of $640 \mathrm{ppm}$ or $640 \mathrm{mg} / \mathrm{L}$. The technique involves measuring the current between two electrodes while allowing sufficient water to dissolve the salts.

\subsection{Types of Salinity}

The Table 2 below gives a broad definition of salinity classes and their effects on vegetation I'C value of $4 \mathrm{ds} / \mathrm{m}$ is assigned or regarded to be division between a non saline and saline soil. Thus, to give some perspective to the values, the maximum limit for human drinking water is a $\mathrm{KC}$ value of $2.5 \mathrm{ds} / \mathrm{m}$, while the I'C value of the Pacific Ocean is approximately $59 \mathrm{ds} / \mathrm{m}$.

It is worthy to note that the classification in the tabular form below of salinity on agricultural crops is equally considered a reasonable classification for salinity in urban centres.

Table 2. Factors for connecting EC (1.5) to ECe

\begin{tabular}{cc}
\hline Soil texture group & Multiplication Factors \\
\hline Sands & 17 \\
Sands loams & 14 \\
Loams & 10 \\
Clay loams & 9 \\
Light clays & 8.5 \\
Light Medium clays & 8 \\
Medium clays & 7 \\
Heavy clays & 6
\end{tabular}

Source: Lindahl Annahl (2009).

\subsection{Concrete}

A composite materials consisting of building medium or glue i.e. cement and water) in which particles of a relatively inert filter materials (i.e. sand and granite aggregate) are embedded is called concrete. Properties of a concrete is improved or modified occasionally through the application of materials called ADMIXTURE. The basic components constituting materials in a concrete are cement, fine and coarse aggregate (gravel or granite) and water. Admixtures are occasionally added.

\subsubsection{Strength of Concrete}

The maximum load or stress a concrete could withstand is referred to as its strength. The potential strength of concrete is determined by the properties and composition of its embedded material. The compressive strength of concrete is commonly used in the construction industry for the purpose of specification and quality control. A primary function of all structures is to carry load or resist applied forces of whatever nature, other functions such as retention of fluids, or exclusion of water or other destructive agents may be involved too in order to maintain sonority of structure without failure or cranking tensile strength of special, importance, although its actual magnitude is relatively low, usually steel, reinforcement is provided to resist tensile forces. The proportion of water to cement determines the strength, the age of the concrete, the quality as well as the mix and shape of the specimen tested. A specimen tested for compressive strength will have a higher indicated strength if the specimen is dry before testing whereas flexural strength will be lower in a dry specimen, strength must be carefully planned, designed and controlled.

\subsubsection{Compressive Strength of Concrete}

The compressive strength of concretes constitutes one of its most significant and useful properties and is the most easily determined. The compressive strength of concrete is taken as the maximum compressive load it can 
carry per unit area. Concrete strength of up to $80 \mathrm{~N} / \mathrm{mm}^{2}$ can be achieved by selective use of the type of cement, mix proportions, method of compaction and curing conditions. Since the compressive strength constitutes an important and useful properties, it is used as a measure of overall quality of the concrete and thus as an indication of other properties relating to determination of durability.

\subsubsection{Tensile Strength}

An important factor often considered in constructing or designing concrete road is its tensile strength. For instance, its flexural strength or modulus of tensile strength in building is utilized for distributing the concentrated loads over a wider area of road pavement. Concrete members are also required to withdraw tensile stress resulting from any restraints to contraction due to drying or temperature variation. Unlike metals, it is quite uneasy to measure concrete strength and as such indirect methods have been introduced to assess this property. Of these methods is the "split cylinder test" being the simplest and most popularly used. The tensile strength of concrete is usually taken to be below its compressive strength. This may vary, however depending on the method used for measuring tensile strength and type of concrete.

\subsection{Some Consequences of the Use of Saline Water as Mixing Water or Curing Water}

Saline water actually increases the risk of corrosion of embedded reinforcing steel, if the structure is to be exposed to air service. Corrosion is promoted by the salt entering concrete through mixing or curing water. This chloride reduces the $\mathrm{pH}$ value and the salt collected in different concentrations in the free water contained in the concrete. Formation of self cells make it impossible to completely put an end to galvanic action because the anodes and cathodes may be switched in an attempts are made to repair the deteriorated concrete. However, seawater has been used on an installation in pacific island when fresh water was scarce. Its usage results in a gain in strength, lower values of water vapour transmission, and accelerated sets (Bryant, M., 1964). The risk on corrosion of steel limits the use of saline water in reinforced concrete and many prohibited its usage in pre stressed concrete.

\subsection{Salinity and Compressive Strength of Concrete}

The most commonly considered valuable property of concrete is its compressive strength, although in many practical cases, other characteristics such as durability, impermeability, volume and stability may in fact be more important.

Yet, the overall picture of the quality of concrete is usually provided by its compressive strength. Obviously water satisfactorily used for mixing is as well suitable for curing purpose. However, there are some conditions of curing concrete for coastal structures that often occur and required special consideration. When concrete is cured with seawater it required maintaining moist environment by sealing materials, use of water, sprays, steam or saturated cover materials, all of which must be kept continuously wet. Indeed, salt water has been used for curing important structure in the past, recent research concerning salt-cell formation and galvanic corrosion of the reinforcing steel indicates that only fresh water is professionally used in curing concrete.

Previous investigations and researches carried out regarding the effect of salt water on the compressive strength of concrete either as mixing or curing water or even both, has over the time produced undependable outcomes which shows contradictions in the final result. The reports of the past studies revealed that when saline water is used as mixing water, the strength of concrete decrease, while recent studies indicated increasing strength. Even thought the aggregate only undergoes little changes. There is the possibility that the changing chemistry and or the grinding of cement may be responsible so that the small differences in properties often observed could not be treated in a statistical fashion thus compounding the uncertainty of the action off salt. Bryant, M. (1964), Taylor and Kuwari (1978) carried out an experiment to determine the effect of ocean salts on compressive strength of concrete cast and cured with salt water. Hence they observed among other things that there were varying percentage increment in strength gained after 28 days depending on the cement brand and possible sea salt $(\mathrm{NaCl}$, $\mathrm{MgCl}_{2}, \mathrm{Na}_{2} \mathrm{SO}_{4}$, or $\mathrm{CaCl}_{2}$ ). They also observed that some chemical processes or reaction must have taken place. From this inconclusive experimental report of Bryant, Taylor and Kuwari, it was recommended that further test are needed. From the conclusion of the study, it was suggested that further research is needed to investigate the basic mechanism involve, and ascertain the influence and importance of such salts so as to monitor the strength at different ages and to investigate the effects of salt upon the other important characteristic of concrete such as shrinkage, creep etc and after the construction of building.

\subsection{Effects of Salinity on Concrete}

As said earlier, the direct action of soluble salts results in salt attack, while the problems associated with salinity are often regarded to simply as salt damp, it is important to note that there exist many different salts that can be 
present, each possessing a different deterioration mechanism in terms of concrete. Since the usual test for salinity is the electrical total conductivity test which measures only the total soluble salt, it provides not an indication as to which types are present by knowing the composition of salts present, but precise assessment of the salt attack mechanism and durability requirements of concrete elements can be made and more effective salinity management strategies are implemented. Salt attacks on concrete can be in the following ways:

- $\quad$ Physical attack

- Chemical attack

- Corrosion of reinforcement

Table 3 below shows different effects of saline water on concrete element as noted by different works of past scholars.

Table 3. Past observations of effects of saline water

\begin{tabular}{|c|c|c|}
\hline Salts & Observations & References \\
\hline $3.5 \%$ & $\begin{array}{c}\text { Water cured: stronger at } 3 \text { days and } \\
7 \text { days wearers after } 28 \text { days air } \\
\text { cured: lower at } 3 \text { months later }\end{array}$ & Abrams A.D.Anons \\
\hline Synthetic sea & $\begin{array}{l}\text { Increase the compressive strength } \\
\text { of the concrete by the presence of } \\
\mathrm{NaCl} \text { in the mixing water }\end{array}$ & Abrams A.D.Anons \\
\hline $\begin{array}{l}\text { Great salt lake }(20 \% \text { sodium } \\
\text { chloride })\end{array}$ & $\begin{array}{c}0.65 \text { to } 0.70 \text { strength at } 28 \text { days and } \\
\text { over }\end{array}$ & Abrams A.D.Anons \\
\hline $\begin{array}{c}\text { Davils Lake }(0.15 \% \mathrm{NaCl}, 0.15 \\
\left.\mathrm{Na}_{2} \mathrm{SO}_{4}\right)\end{array}$ & Showed no ill effect & Abrams A.D.Anons \\
\hline $\begin{array}{l}\text { Medical lakes }(3.5 \% \text { mostly } \\
\mathrm{MaSO}_{4} \text { from drains and streams in } \\
\text { sulphate districts }\end{array}$ & $\begin{array}{l}\text { Similar to sea water, sometimes } \\
\text { lower to problems up to age } \\
21-24 \text { years }\end{array}$ & Abrams A.D.Anons \\
\hline Sodium chlorides & $\begin{array}{l}\text { With types II cement } \mathrm{NaCl} \text { increase } \\
\text { in strength reduces water vapour } \\
\text { transmission. An optimum at } \\
\text { approve } 3.6 \% \text { was noted and large } \\
\text { salinity cold be tolerated before the } \\
\text { strength dropped below the } \\
\text { strength of fresh water concrete. } \\
\text { Results similar for age of } \\
28,56,112,224 \text { and } 364 \text { days }\end{array}$ & Griffin and Henry \\
\hline Ocean Salts & $\begin{array}{l}\text { Strength increase with salinity of } \\
\text { mixing water }\end{array}$ & $\begin{array}{c}\text { Cement and Concrete Association } \\
\text { London }\end{array}$ \\
\hline
\end{tabular}

Source: Fatokun (2005).

\subsubsection{Physical Attack}

Entrance of soil moisture into the concrete leads to rising damp and crystallization of salts (both chlorides and sulphates) as the water evaporates. Owing to the pressure exerted by the crystallization process and the strength of the concrete, some disruption of the concrete at the surface layer of the concrete may be softened and possibly fret away, exposing a fresh surface. Introduction of buried concrete elements prevents the exposure to attack of the fresh surfaces while the soften layer will typically slow down the rate at which further concrete will be attacked.

\subsubsection{Chemical Attack}

Alongside the chloride ions contained in saline ground water environments are naturally occurring sulphates of sodium, potassium, calcium or magnesium. At certain concentrations, these sulphates can chemically attack the concrete. The severity of the attack will depend on the types of sulphate present, their concentration, and movement of groundwater, pressure, temperature and the pressure of other ions, potential sources source include:

- Groundwater containing dissolved sulphate

- Dissolved sulphate formed from oxidation of sulphide minerals in the ground 
- Sulphate from back fills of coal ash or coal washers reject

Sulphate attack typically involves a reaction between the sulphate and constituents of the concrete to form products. The resulting swelling within the concrete leads to cracking which in turn allows easier access for further penetration of aggressive elements thus leading to further deteriorating. Attack from calcium, sodium and potassium sulphate is classified as "moderate" while magnesium and ammonium sulphate are potentially more severe in their action. This is because they attack a greater number of the concrete constituents.

\subsubsection{Corrosion of Reinforcement}

Highly alkaline environment ( $\mathrm{pH}$ around 12) is provided by the concrete surrounding reinforcement, which results in the steel being preserved and protected by forming a strong impermeable oxide layer on its surface. This automatically protects the steels from corrosion (i.e. moisture and oxygen). The concrete cover to the reinforcement provides a physical barricade to the ingress of substances such as salts. Proportionately, as the severity of the exposure increase, so is the required quality of the concrete cover. There exist two major protective mechanisms of how steel can be impaired and corrosion initiated (see the result of water analysis in Table 4 below).

- $\quad$ Reduction in the alkalinity of the concrete, which prevents the protective oxide layer forming

- Ingress of salts such as chloride, which if present in sufficient concentration causes corrosion even in an alkaline environment

Table 4. Water analysis results for ocean and lagoon water

\begin{tabular}{ccc}
\hline Parameter & Ocean Water & Lagoon Water \\
\hline -PH & 6.69 & 6.94 \\
Acidity $(\mathrm{Mg} / \mathrm{I})$ & 12.97 & 25.94 \\
Alkalinity $(\mathrm{Mg} / \mathrm{I})$ & 160.66 & 114.74 \\
Chloride $(\mathrm{Mg} / \mathrm{I})$ & 18379.18 & 13697.69 \\
Sodium Chloride $(\mathrm{Mg} / \mathrm{I})$ & 46000 & 22601.19 \\
Conductivity $(\mathrm{Mg} / \mathrm{I})$ & 46000 & 53000 \\
Sulphate $(\mathrm{Mg} / \mathrm{I})$ & 99.90 & 98.44 \\
Nitrate $(\mathrm{Mg} / \mathrm{I})$ & 15.51 & 18.61
\end{tabular}

Source: Laboratory Analysis (2006).

\section{Research Methodology}

The research methodology investigated and report on the effects of salt in saline water (Lagoon and Ocean water on both reinforced and mass concrete structures in the coastal regions.) The primary data for the research work comprises review of researches conducted on concrete while the secondary data includes the relevant past laboratory record (Published and unpublished), In addition a laboratory experiment was conducted to determine saline water effects on compressive strength of concrete. The three approaches used are:

- $\quad$ Casting and curing of the concrete cube and beams samples using ocean water labelled (OOW)

- $\quad$ Casting and curing of the concrete cube and beam samples using lagoon water labelled (LLW)

- $\quad$ Casting and curing of the concrete cube and beam samples using fresh water labelled (FFW) - Control $\operatorname{mix}$

Concrete samples were cast and buried in an isolated concrete tank filled with ocean bed sand, lagoon sand and fresh water sand. These tanks were reticulated with ocean water, lagoon water and fresh water. The cast concrete element comprises of $150 \mathrm{~mm} \times 150 \mathrm{~mm}$ cubes for ocean bed, lagoon and freshwater bed with $1500 \mathrm{~mm} \times 300 \mathrm{~mm}$ $\mathrm{x} 300 \mathrm{~mm}$ reinforced concrete beam cast and cured with ocean water, lagoon water and fresh water. The mixes were prepared in the laboratory in the ratio 1:3:6 of cement, sand and coarse aggregates. The control mix (FFW) and the two additional mixes (OOW and LLW) as described above were prepared to ascertain the effect of sea and lagoon water on the compressive strength of reinforced concrete. These specimens were observed for 7 days, 14 days, 21 days, and 28 days up to 150 days to allow for compressive strength development before crushing with compressive crushing machine. All the cubes were cured by total submersion in water. 
Characterization of aggregates, mixing and preparation of concretes and compressive strength test were performed in accordance with ASTM standards. A water cement ratio of 0.41 was used in all mixes.

This approach was adopted to provide basis for qualitative comparism of how different types of saline water affect compressive strength of concrete when they are used for casting and curing of concrete.

The striking of the moulds used for various concrete specimens were done immediately after $24 \mathrm{hrs}$ (twenty-four hours) of casting and the various samples were placed into the various water and the environment of curing as shown in tables of the appendix.

Table 5. Curing arrangements for cube

\begin{tabular}{|c|c|c|c|c|}
\hline Batch No. & Samples & Batch Designation & Description & $\begin{array}{c}\text { No. of Reinforced } \\
\text { Beam }\end{array}$ \\
\hline A & $\begin{array}{c}\text { Reinforced } \\
\text { Beam }\end{array}$ & FFS & $\begin{array}{l}\text { Concrete cast in fresh water and } \\
\text { cured with fresh water }\end{array}$ & Four(4) \\
\hline B & Reinforce & OOS & $\begin{array}{l}\text { Concrete cast with ocean water and } \\
\text { cured in the ocean sand }\end{array}$ & Four(4) \\
\hline $\mathrm{C}$ & Reinforce & LLS & $\begin{array}{l}\text { Concrete cast with lagoon water } \\
\text { and cure with lagoon sand }\end{array}$ & Four(4) \\
\hline
\end{tabular}

Source: Laboratory Analysis (2009).

\section{Discussion of Results}

\subsection{Result of N-type Schmidt Hammer for Reinforced Beam}

It is noted that due to the unavailability of the crushing machine that could be used to carry out crushing test on the reinforced concrete beams, a Schmidt hammer test was alternatively carried out with a sample on the cube specimen first before the reinforced concrete beam proper. This was done for proper analysis and for computation of the result obtained for the purpose of interpolation. (See Table 6, 7 and 8 below) This experiment was anchored on the fact that larger percentage (about 70\%) of the indigenous contractor who usually execute construction work on private based-construction company were found to be constant user of between 1:3:5 and 1:3:6. Concrete mix ratio.

Table 6. Average compressive strength of concrete (cubes) fresh, lagoon \& ocean water

\begin{tabular}{cccc}
\hline Curing Days & $\begin{array}{c}\text { Average Compressive } \\
\text { Strength }\left(\mathrm{N} / \mathrm{mm}^{2}\right) \text { Fresh }\end{array}$ & $\begin{array}{c}\text { Average Compressive } \\
\text { Strength }\left(\mathrm{N} / \mathrm{mm}^{2}\right) \text { Ocean }\end{array}$ & $\begin{array}{c}\text { Average Compressive } \\
\text { Strength }\left(\mathrm{N} / \mathrm{mm}^{2}\right) \\
\text { Lagoon }\end{array}$ \\
\hline 7 & 14.20 & 10.65 & 10.57 \\
14 & 17.48 & 12.10 & 12.55 \\
21 & 20.92 & 17.05 & 18.04 \\
28 & 24.06 & 18.67 & 19.66 \\
30 & 22.77 & 17.14 & 21.67 \\
60 & 24.05 & 20.42 & 21.98 \\
150 & 25.49 & 20.80 & 22.90 \\
\hline
\end{tabular}

Source: Laboratory (2001). 
Table 7. Schmidt test on cube @ 28 days

\begin{tabular}{|c|c|c|c|c|}
\hline Batch & Description & Means Reading & $\begin{array}{l}\text { Schmidt Hammer } \\
\text { value on graph } \\
\mathrm{Kg} / \mathrm{cm}^{2}\end{array}$ & $\begin{array}{l}\text { Crushing Result } \\
\mathrm{N} / \mathrm{mm}^{2}\end{array}$ \\
\hline FFW & $\begin{array}{l}\text { Concrete cube } \\
\text { casted with fresh } \\
\text { water and cured } \\
\text { with fresh water }\end{array}$ & $32.2 \%$ & $210 \mathrm{Kg} / \mathrm{cm} 2$ & $21.0 \mathrm{~N} / \mathrm{mm} 2$ \\
\hline OOW & $\begin{array}{l}\text { Concrete cube } \\
\text { casted with ocean } \\
\text { water and cured } \\
\text { with ocean water }\end{array}$ & $24.5 \%$ & $180 \mathrm{Kg} / \mathrm{cm} 2$ & $16.0 \mathrm{~N} / \mathrm{mm} 2$ \\
\hline LLW & $\begin{array}{l}\text { Concrete cube } \\
\text { casted with lagoon } \\
\text { water and cured } \\
\text { with lagoon water }\end{array}$ & $27.5 \%$ & $180 \mathrm{Kg} / \mathrm{cm} 2$ & $18.0 \mathrm{~N} / \mathrm{mm} 2$ \\
\hline
\end{tabular}

Source: Laboratory Experiment (2009).

Table 8. Average compressive strength (Schmidt hammer test) for reinforced concrete beam

\begin{tabular}{|c|c|c|c|}
\hline Curing days & $\begin{array}{c}\text { Average Compressive } \\
\text { Strength }\left(\mathrm{N} / \mathrm{mm}^{2}\right) \\
\text { Fresh Water }\end{array}$ & $\begin{array}{l}\text { Average Compressive } \\
\text { Strength }\left(\mathrm{N} / \mathrm{mm}^{2}\right) \\
\text { Ocean Water }\end{array}$ & $\begin{array}{l}\text { Average Compressive } \\
\text { Strength }\left(\mathrm{N} / \mathrm{mm}^{2}\right) \\
\text { Lagoon Water }\end{array}$ \\
\hline 28 & 20.8 & 16.9 & 18.0 \\
\hline 30 & 23.0 & 23.0 & 19.5 \\
\hline 60 & 23.9 & 19.0 & 20.6 \\
\hline 90 & 24.2 & 21.0 & 23.6 \\
\hline 150 & 24.9 & 22.4 & 24.05 \\
\hline
\end{tabular}

Source: Laboratory Experiment (2009).

\subsection{Summary of Findings}

At the expiration of 150days of the research work, the following observations were noted as listed below:

- That, concrete sample (cube) cast and cured with fresh water gained appreciable strength with age. Though, there was a slight decrease in the strength but later on, the strength was recovered and the increase in strength became steady.

- $\quad$ That the sample cast and cured with both lagoon and ocean water slowly increase in strength. The strength increment continued over the period of the experiment but the values were lower when compared with the past record of findings of previous study (Fatokun, 2005).

- That the strength of concrete eventually increase due to the presence of salt content but its resultants effect on reinforcement will be alarming if proper care is not taken.

- That due to the steady increase in strength of concrete (including reinforced concrete) structure; it affords elongated life of the structure by providing the desired strength in a steady manner.

The strength of reinforced concrete samples with ocean and lagoon water gained strength steadily over a period of time but with values lower than the rate of the sample with fresh water sample which in turn is lower than previously observed records. Values of samples cast with 1:3:6 mix is also considerably lower than previous studies carried out with 1:2:4 mix (Fatokun, 2005).

\section{Conclusion and Recommendation}

Concrete cast and cured with fresh water increases in strength in gradual manner and the result quite agrees with the value of the compressive strength 1:2:4 of the generally acceptable standard in 28 days. However, for the acceptable strength of between $23 \mathrm{~N} / \mathrm{mm}^{2} 25 \mathrm{~N} / \mathrm{mm}^{2}$ to be attained with mix ratio $1: 3: 5$, it was experimentally observed that the same number of days ( 28 days) will not suffice the strength, the strength required will not be attained on the same specified day for both 1:2:4 and 1:3:6 concrete mix. Hence, the above is imperative in the stripping of the individuals section of reinforced concrete structure. That is, if a 1:2:4 mix reinforced concrete 
attains strength in 28days, thus, necessitating the stripping of the form, the same must not be done for 1:3:6, that is, its stripping should be done after having observed that the design strength is reached. This is usually beyond 28 days.

The saline and lagoon water used for the experiment were also found to have effect on the compressive strength of the concrete from the result of the experiment.

Well compaction is required for concrete work under saline condition and adequate cover in order to present void and ingress of salts water into touching the reinforcement.

- $\quad$ Special cement like sulphate resisting should be used in any environment where there are possibilities of ingress of salt containing chloride or sulphate ions

- $\quad$ Strict adherence should be given to specifications most especially in any issue concerning reinforced concrete structures

- The designed strength of each element of reinforced concrete structure should be attained before stripping of the forms for the members

\section{Reference}

Adebakin, H. I. (2003). Effect of Salinity on Compressive Strength on Concrete.

Bella, M., \& Fabuss, T. (1989). Properties of Seawater. $1^{\text {st }}$ Edition Academic Press Boston.

Bryant, M. (1964). Effects of Seawater on Concrete. Miscellaneous paper no 6-690, U.S. Army Engineers, Waterways experiment station, Corps of Engineers, Vicks berg, Mississippi.

Cohen, M. D., \& Bentur, A. (1988). Durability of Portland cement Silica fume paste Magnesium Sulphate and Sodium Sulphate solution. Material Journal, 85-98.

Fatokun, A. O. (2005). Salinity Effect in Reinforced Concrete Buildings. Unpublished HND Thesis at Department of Building, Yaba College of Technology Nigeria.

Footes, P. G., \& Mettan, J. D. (1998). Concrete Deterioration and Corrosion of Steel in Marine Environment. Cement and Concrete association.

Gain, M. S. (1997). Cement and Concrete. $1^{\text {st }}$ Edition Champion and Halls New York.

Global Construction. (2003). Conference paper Delivered at $1^{\text {ST }}$ International Conference of Department of Building, University of Lagos, Nigeria.

Jackson, N. (1984). Civil Engineering Material. $4^{\text {th }}$ Edition English Language Book Society / Macmillan London.

Less, T. P. (1992). Deterioration Mechanism. Butterworth London.

Lindohlm, A. M. (2009). Sources of Pesticides Loses to Surface Waters and Ground Water at Field and landscape scales. A published Doctoral Thesis submitted to Swedish University of Agricultural Sciences, Uppsala, Switzerland.

Michael, A. T., \& Kuwaini, S. (1978). Effect of ocean water salt on the compressive Strength of the Compressive strength of concrete. Cement and Concrete Research, 8, 492-500.

Osei, Y. A. (2000). Neutralization, New School Chemistry” African First Publisher Onitsha Nigeria.

Oyenuga, V. O. (2004). Design and Construction of Foundations (A practical approach) $1^{\text {st }}$ Edition by Asros Ltd. Lagos Nigeria.

Prascal, J., Jain, D. K., \& Ahuja, A. K. (2006). Factors Influencing the Sulphate Resistance of Cement, Concrete and Mortar. Asian Journal of Civil Engineering (Building and Housing), 7(3), 259-268.

Scott, G. (1976). Building Disaster and Failure Construction Press Ltd. Hornby Lancaster.

Swam, R. N. (1992). The Alkali Silica Reactions in Concrete van Naostrand Reinhold New York.

Water Encyclopaedia. (2012). Earth: The water Planet, (Ed). Earth Sylvia. Retrieved from www.watercyclopedia.com/ Da-En/ Earth- The water-planet.html \# b 